\title{
LEGAL
}
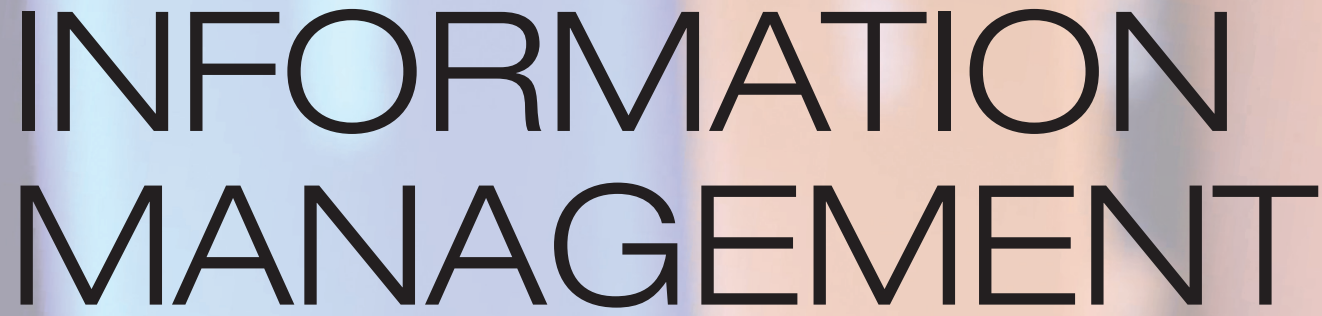

Journal of the British and Irish Association of Law Librarians

Volume 12 Number 42012 


\title{
CAMBRIDGE
}

\section{INTERNATIONAL LAW REPORTS}

\author{
Edited by ELIHU LAUTERPACHT \\ University of Cambridge \\ and CHRISTOPHER GREENWOOD \\ International Court of Justice \\ Assisted by KAREN LEE \\ University of Cambridge
}

Prepared at the famous Lauterpacht Research Centre for International Law at the University of Cambridge, this is the only publication devoted to the regular and systematic reporting in English of decisions of international courts and arbitrators, as well as judgements of national courts.

It is an essential resource for all practitioners and academics in the field of international law and an important addition to every law library:

- The most authoritative publication in international law, featuring cases from 1919, to the present

- The only publication to provide comparable coverage of case law in this field

- Cases are drawn from every relevant jurisdiction - international and national

- Regularly updated with up to 6 volumes published each year, and 150 volumes currently available

Volumes are available to buy individually or as a set comprising all published volumes.

Set ISBN 978-0-521-46926-5

For more information, including the cases covered in each volume

visit www.cambridge.org/ilr

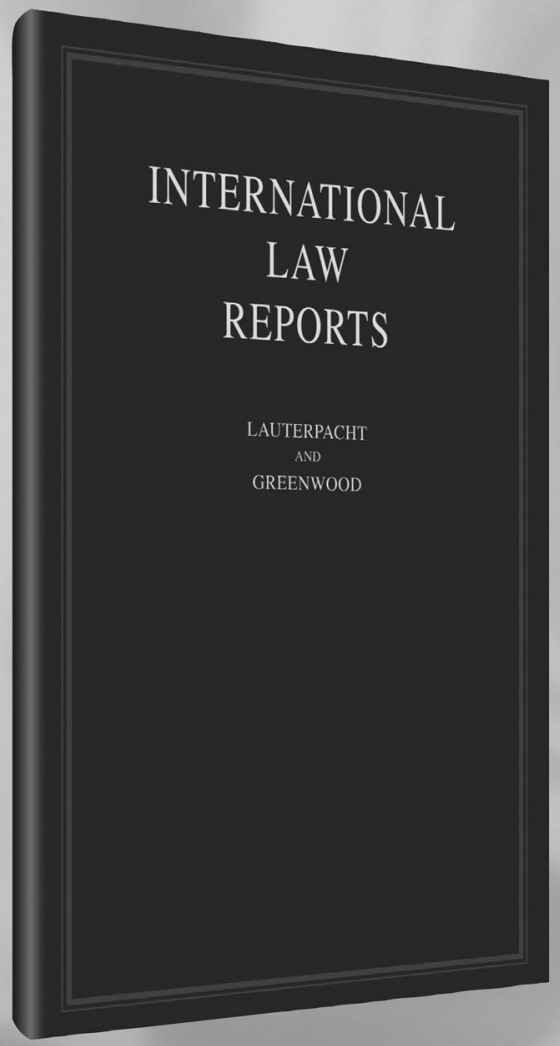




\section{Legal Information Management}

Journal of the British and Irish Association of Law Librarians

\section{Contents}

Editorial

In Memoriam: Sarah Spells

James Mullan

\section{SELECTED PAPERS DELIVERED AT THE BIALL CONFERENCE}

Lines on Maps and the Frontiers of Legal Research 246

What Makes An Important Case? An Agenda for Research

John Morison

The Uniqueness of Northern Ireland Public Law 262

Gordon Anthony

Legal Skills: Ensuring 'Appy students

Research@Mofo: Providing a Virtual Enquiry Service

Communication, Culture and Context: Best Practice for Working Internationally Sara Batts, Jas Breslin and Susanna Winter

From Oxford to Williamsburg: Part I - The University of Oxford, Faculty of Law and Bodleian Law Library

Ruth Bird

From Oxford to Williamsburg: Part 2 - The College of William \& Mary Law School and Wolf Law Library

James S. Heller

\section{INTERNATIONAL PERSPECTIVES}

Discovering the Digitised Law Library of Heritage Collections: A Collaborative Achievement Between French Libraries

Claire Bonello

\section{OCCASIONAL SERIES}

Conversations with Emeritus Professor Stroud Francis Charles (Toby) Milsom: 305 A Journey from Heretic to Giant in English Legal History Lesley Dingle

\section{CURRENT ISSUES}

The Future of Legal Research 


\section{Legal Information Management \\ Published on behalf of the British and Irish Association of Law Librarians www.biall.org.uk}

\section{Editor}

David Wills, B.A. M.A.(Cantab) Dip.Lib. MCLIP

Squire Law Library, 10 West Road, Cambridge, CB3 9DZ

Tel: $0122335007 \mid$

Email: dfw1003@cam.ac.uk

\section{Editorial Board}

Paul Banks, M.A. Dip. Lib.

The City Law School, London, UK

Julie Doran, B.A. (Hons) M.A. MCLIP PGCE (FE/HE)

(Book \& Product Review Editor)

University of Gloucestershire, Cheltenham, UK

Sarah Froggatt, B.A. Dip. Lib.

Reynolds Porter Chamberlain LLP, London, UK

Julie Keys, B.A. Dip. Ed. Dip. Inf.

Fox Williams LLP, London, UK (and Freelance

Consultant)

Wendy Lynwood, B.A. M.A. MCLIP

Birkbeck, University of London, UK

Pattie Punch, M.A.

University of Limerick, Ireland

Katherine Read, B.A. M.A. MCLIP (Current Awareness Editor) Institute of Advanced Legal Studies, London, UK

Dunstan Speight, M.A. (Oxon.) M.Sc. Econ. (Chair)

Berwin Leighton Paisner LLP, London, UK
Legal Information Management is the official journal of the British and Irish Association of Law Librarians. Aimed at professionals active in the legal information community this topical journal provides invaluable information for all those involved in the provision of legal information in the academic and professional environments. Published quarterly, and with an extensive current awareness section, a regular internationally focused article and coverage of management issues, Legal Information Management is the international journal for legal information professionals everywhere.

\section{Subscriptions}

Legal Information Management (ISSN I472-6696) is published quarterly in March, June, September and December. Four parts form a volume. The subscription price which includes delivery by air where appropriate (but excluding VAT) of volume 12, 2012, which includes print and electronic access, is $£ 128$ (US \$2II.00 in USA, Canada and Mexico) for institutions. The electronic-only price available to institutions is $f \mid 18.00$ (US $\$ 190.00$ ). Single parts are $£ 34.00$ (US $\$ 55.00$ in USA, Canada and Mexico) plus postage. EU subscribers (outside the UK) who are not registered for VAT should add VAT at their country's rate. VAT registered members should provide their VAT registration number. Japanese prices for institutions (including ASP delivery) are available from Kinokuniya Company Ltd, P.O. Box 55, Chitose, Tokyo 156, Japan.

Orders, which must be accompanied by payment, may be sent to a bookseller, subscription agent or direct to the publisher: Cambridge University Press, The Edinburgh Building, Shaftesbury Road, Cambridge CB2 8RU; or in the USA, Canada and Mexico: Cambridge University Press, 40 West 20th Street, New York, NY I00I-42I I. Periodicals postage paid at New York, NY and at additional mailing offices.

\section{Copying}

This journal is registered with the Copyright Clearance Center, 222 Rosewood Drive, Danvers, MA 01923, USA. Organizations in the USA who are also registered with the C.C.C. may, therefore copy material (beyond the limits permitted by, sections 107 and 108 of U.S. Copyright law) subject to payment of the C.C.C. of the per copy fee of $\$ 10.50$. This consent does not extend to multiple copying for promotional or commercial purposes. Code I472-6696/I2. ISI Tear Sheet Service, 350I Market Street, Philadelphia, PA 19104, USA, is authorized to supply single copies of separate articles for private use only. Organizations authorized by the Copyright Licensing Agency may also copy material subject to the usual conditions. For all other use, permission should be sought from Cambridge or from the American Branch of Cambridge University Press. Legal Information Management is included in the Cambridge Journals Online journals service which can be found at http://journals.cambridge.org. For further information on other Press journals access http://cambridge.org/journals.

Legal Information Management is indexed in Current Law Index, Legal Information Management Index, Legal Journals Index, Library Literature and Information Science. Legal Information Management also appears in full-text on Westlaw.

(C) British and Irish Association of Law Librarians and Contributors 2012 ISSN 1472-6696

\section{Cambridge University Press}

The Edinburgh Building, Cambridge CB2 8RU, UK 40 West 20th Street, New York, NY I00 I I-42 I I, USA 477 Williamstown Road, Port Melbourne, VIC 3207, Australia Ruiz de Alarcn 13, 280|4, Madrid, Spain

Dock House, The Waterfront, Cape Town, 800I, South Africa

Printed in the United Kingdom by Latimer Trend, Plymouth 